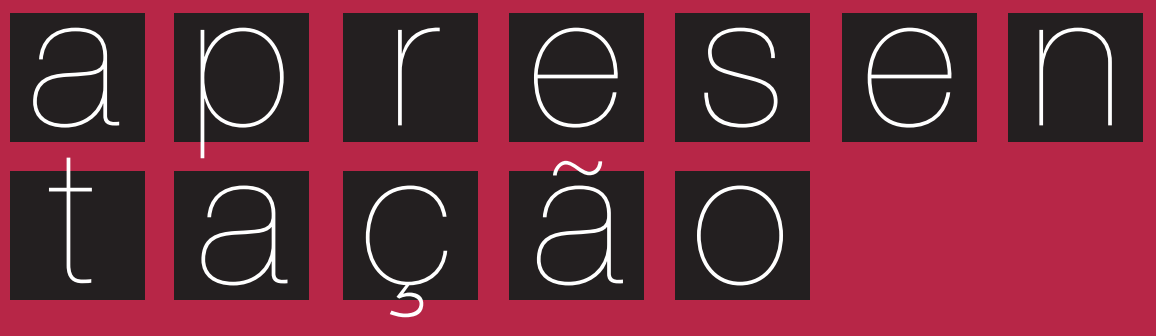


Consumo. Mídia. Cultura.

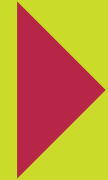




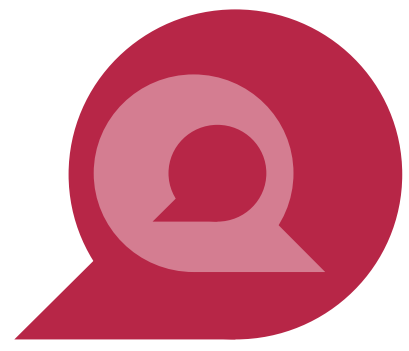

\section{O fim de um ciclo é sempre o começo de outro}

\section{HERTZ WENDEL DE CAMARGO *}

É com grande satisfação que chegamos à $14^{a}$ edição da revista Ação Midiática. Apresentamos o dossiê "Consumo e Comunicação", organizado pelos professores pesquisadores Lilian Muneiro (UFRN) e Aryovaldo de Castro Azevedo Junior (UFPR). Conforme os organizadores, o dossiê traz 14 artigos de pesquisadores de diferentes instituições de ensino superior, sendo dois deles internacionais, especificamente da Argentina e México. A partir da próxima edição, a revista segue sob a direção dos editores Carla Rizzotto e José Carlos Fernandes, professores e pesquisadores do PPGCOM-UFPR.

Além do dossiê, apresentamos cinco artigos de diferentes abordagens nos campos da comunicação, cultura e sociedade. O primeiro artigo tem como título Poder, território e discurso: os suábios do Danúbio em Guarapua$v a-P R$, assinado pelos autores Márcia da Silva e Gilson Aparecido Boschiero, pesquisadores da Universidade Es-

\footnotetext{
* Professor do Programa de Pós-Graduação em Comunicação da Universidade Federal do Paraná (UFPR), editor da Revista Ação Midiática. Doutor em Estudos da Linguagem (UEL), líder do grupo de pesquisa no CNPq, Estudos em Comunicação, Consumo e Sociedade (ECCOS).
} 
tadual do Centro-Oeste (Unicentro). O artigo apresenta uma leitura sobre os imigrantes denominados de "Suábios do Danúbio" a partir dos discursos produzidos e reproduzidos historicamente pelos próprios imigrantes, pela sociedade e pela mídia.

Outro artigo é assinado pelos pesquisadores da Universidade Federal do Amazonas (UFAM), Gilson Vieira Monteiro, Adriano da Silva Rodrigues e Rafael de Figueiredo Lopes. O artigo A Rebelião no Compaj e a Estética da Violência no Contexto Cibercultural e Ecossistêmico propõe uma reflexão sobre a estetização da violência no contexto da cibercultura a partir de apontamentos sobre a rebelião no Complexo Penitenciário Anísio Jobim (Compaj), em Manaus no início de 2017, seguindo o viés dos Ecossistemas Comunicacionais.

O artigo Trabalho e mídia: construções discursivas sobre o universo do trabalho no Brasil em conteúdos jornalísticos, de autoria de Angela Maria Rubel Fanini e Erike Luiz Vieira Feitosa, ambos pesquisadores da Universidade Tecnológica Federal do Paraná (UTFPR). O artigo analisa construções discursivas a respeito do trabalho e do trabalhador em editoriais de veículos de comunicação que versam sobre uma suposta improdutividade do brasileiro e também em reportagens sobre pessoas em situações de trabalho degradantes.

$\mathrm{O}$ quarto artigo intitulado $O$ conteúdo relevante nas redes sociais da Oktoberfest Blumenau, autoria dos pesquisadores da Universidade Regional de Blumenau (FURB) Clóvis Reis, Moisés Cardoso e Luísa Rozinski 
Dias do Nascimento, analisou a produção de conteúdo midiático da Oktoberfest Blumenau no Facebook, considerando seu objetivo de comunicação e aspectos fundamentais da redação publicitária.

Esta edição ainda traz o artigo ensaístico do pesquisador e professor Rodolfo Rorato Londero (PPGCOM -UEL) sob o título "Bem-vindo à próxima fase": a cultura do choque e o fim do tédio. $\mathrm{O}$ autor discute o conceito de choque, desde sua formulação como técnica comercial pela publicidade até suas consequências para o atual regime de atenção. Ainda propõe como a intensificação do choque a partir do consumo exagerado de imagens, como o percebido na cultura dos videogames, contribui para o fortalecimento de uma atenção fragmentada e inquieta do homem contemporâneo.

A edição ainda traz duas resenhas. A primeira, de autoria de Lucimara de Sousa Teixeira e Adriana Aparecida de Lima Terçariol - ambas da Universidade Nove de Julho (UNINOVE) - e tem como título Construções por meio das tecnologias digitais. Foi produzida a partir da coletânea Da internet para sala de aula: educação, tecnologia e comunicação no Brasil.

A segunda resenha tem autoria de Patricia Bieging (ECA-USP) sob o título Bauman e as identidades multiculturais fluídas e teve como base a obra Identidade: entrevista a Benedetto Vecchi, de Zygmunt Bauman.

Caro leitor, só me resta desejar uma boa leitura e um 2018 com mais conhecimento para você.

O Editor 
Consumption. Media. Culture.

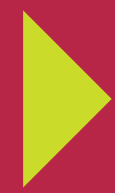




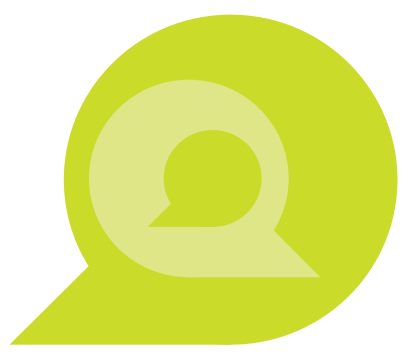

\section{The end of a cycle is always the beginning of another}

HERTZ WENDEL DE CAMARGO *

It is with great enthusiasm that we have published the $14^{\text {th }}$ edition of the Ação Midiática journal. We introduce the dossier "Consumption and Communication", organised by the research professors Lilian Muneiro (UFRN) and Aryovaldo de Castro Azevedo Junior (UFPR). According to the organisers, the dossier presents 14 articles from researchers from different undergraduate and graduate institutions, of which two are international, specifically from Argentina and Mexico. From the next edition on, the journal is under the direction of the new editors; Carla Rizzotto and José Carlos Fernandes, research professors at the PPGCOM-UFPR.

Additionally to the dossier, we present five articles with different approaches in the fields of communication, culture and society. The first is entitled Power, territory and speech: the Danube Swabians in Guarapuava-PR and is written by the authors Márcia da Silva and Gilson Aparecido Boschiero, researchers at the Universidade Estadual

\footnotetext{
* Professor at the Communication Post-Graduation Program of Universidade Federal do Paraná (UFPR). Editor of the journal Ação Midiática. Doctor in Language Studies at Universidade Estadual de Londrina (UEL). Leader of research group at CNPq Communication, Consumption and Society Studies (ECCOS).
} 
do Centro-Oeste (Unicentro). The article presents a study about immigrants known as "Danube Swabians" analysing discourses historically produced and reproduced by the own immigrants, the society and the media.

Another article is written by researchers at the Universidade Federal do Amazonas (UFAM), Gilson Vieira Monteiro, Adriano da Silva Rodrigues and Rafael de Figueiredo Lopes. The article entitled Riot in Compaj and the Aesthetic of Violence in the Context Cybercultural and Ecosystem reflects on the aestheticisation of violence in the cyberculture context based on notes about the rebellion in the Anísio Jovim Penitentiary Complex (Compaj), in Manaus in early 2017, considering the Communication Ecosystems bias.

The article Work and the media: discursive constructions about the universe of work in Brazil in journalistic contents, which authors are Angela Maria Rubel Fanini and Erike Luiz Vieira Feitosa, researchers at the Universidade Tecnológica Federal do Paraná (UTFPR). The article analyses discursive constructions regarding work and the worker in communication vehicles' editorials which deal with a supposed unproductiveness of Brazilian workers and also in news report about people in degrading work situations.

The fourth article is entitled Relevant content on Oktoberfest Blumenau social networks. It is written by the Universidade Regional de Blumenau (FURB)'s researchers Clóvis Reis, Moisés Cardoso e Luísa Rozinski Dias do Nascimento, and analysed the production of Oktoberfest 
Blumenau's media content on Facebook, considering its communication objective and the fundamental aspects of advertising writing.

This edition also brings an essay which author is the research professor Rodolfo Rorato Londero (PPGCOM-UEL) and is entitled "Welcome to the next level": the culture of shock and the end of boredom. The author discusses the concept of shock, from its formulation as a commercial technique used by advertising to its consequences for the current attention regime. He also proposes that the intensification of the shock originated from the excessive consumption of images, such as regarded in the video games' culture, contributes to the strengthening of a fragmented and restless attention of the contemporary man.

This edition also presents two book reviews. The first one is entitled Constructions by digital technologies and is written by Lucimara de Sousa Teixeira and Adriana Aparecida de Lima Terçariol - both from the Universidade Nove de Julho (UNINOVE). It was produced from the collection "Da internet para sala de aula: educação, tecnologia e comunicação no Brasil."

The second book review is written by Patricia Bieging (ECA-USP), entitled Bauman and fluid multicultural identities and was based on the work Identity: Conversations with Benedetto Vecchi, by Zygmunt Bauman.

Dear reader, I wish you a good reading and may your 2018 be fulfilled with knowledge. 